\title{
The influence of low impact development-best management practices implementation on surface runoff reduction: $A$ case study in Universitas Indonesia catchment area
}

\author{
Luluk Azkarini ${ }^{1, *}$, Evi Anggraheni ${ }^{1}$, and Dwita Sutjiningsih ${ }^{1}$ \\ ${ }^{1}$ Department of Civil Engineering, Universitas Indonesia, Depok, Indonesia
}

\begin{abstract}
High population growth rate will increase the infrastructure development, so the impervious land cover in a certain area will be greater. In 2016, the percentage of impervious area in UI Depok catchment area has reached $57 \%$. This condition causes the surface runoff volume and probability of flood will increase. LID is a new paradigm for stormwater management in micro-scale areas. LID infrastructure is designed to manage stormwater for light to moderate rainfall spectrum. Previous research has produced an applied proposal of various LID-BMP infrastructure in UI catchment area, Depok, by using BMP Siting Tools. This study aims to compare the volume of surface runoff without and with the LID infrastructures on UI catchment area, Depok, and to calculate the effectiveness of LID infrastructure for various spectrum of rainfall. The LID infrastructures used are bioretention, porous pavement, infiltration trench, infiltration basin, vegetated filter strip, sand filter non-surface, sand filter surface, rain barrel and grassed swales. By applying said infrastructures, the reduction of peak flow on various rain spectrums vary from $3-30 \%$.
\end{abstract}

\section{Introduction}

In the catchment area of UI campus itself, the percentage of land built in 2016 has reached $52 \%$. With increased impervious cover, the surface runoff volume will increase, resulting in flooding. Flood is an increase in the amount of water that is not contained in the channels, so that overflows and inundate areas outside the channel [1]. According to the hydrological function, the incidence of flooding is when the water level is higher than the normal water level [2]. Some efforts to reduce floods according are to build absorption wells and biopores. Both buildings are the absorption of the LID concept.

Low Impact Development (LID) is a new paradigm in micro-scale rain management conducted in water catchment areas [3]. The understanding of common people in Indonesia is against the LID building, which states that the LID building can reduce flooding. [4] classified the rainfall-runoff building based on its spectrum. In general, LID buildings are

\footnotetext{
*Corresponding author: lulukazkarini@gmail.com
} 
offered only suitable to manage the rain with a light to moderate spectrum. One tool that can be used to simulate LID building laying is the Best Management Practices (BMPs), Siting Tool. BMP Siting Tools is a program developed by the US Environmental Protection Agency (EPA) to help determine the location of the LID building by considering the existing conditions in the catchment area (slope, water level, the soil layer, land ownership, roads, drainage).

\section{Literature review}

Rainwater management concepts must be developed and evaluated following local conditions. Precipitation water should be retained where it falls as far as possible and be evaporated, used, and/or infiltrated through the active soil zone. In addition to using rainwater as process water, other environmentally friendly alternative forms of rainwater management, such as infiltrating precipitation water runoff from roofs and reinforced surfaces as well as building greening options should be examined [5].

Conventional runoff management system uses the old paradigm in rain structure planning that is that rainfall runoff is something that is considered to be conveyed as soon as possible to achieve a good drainage condition [6]. Such development makes the volume, frequency, and discharge runoff great, altering most of the hydrological conditions of the region by causing loss of natural water storage, the concentration-time (Tc) becomes shorter. This incident does not conform to natural features that preclude runoff or infiltrate runoff and prolong the travel time. Thus, conventional rainwater management systems have recently been deemed inhospitable because they have adverse effects on ecosystems.

Low Impact Development (LID) is a way of designing a region with the aim of maintaining and mimicking the hydrological characteristics of an area before development [6]. Low Impact Development (LID) is a site design/land strategy with the aim of maintaining or mimicking the hydrological conditions of a region in pre-development conditions [7]. The techniques employed are hydrological storage (storage), infiltration, evaporating, groundwater recharge and rainwater runoff functions with the provision of small-scale retention and detention areas.

Low Impact Development Method (LID) is one method of rainwater management for very mild to moderate rain events by decreasing runoff volume and controlling water quality on microscale or catchment area. The design rain plan (precipitation) used is for moderate to low rain (rainfall $\leq 50 \mathrm{~mm}$ ), or with a repeat period between 2-10 years (probability 50-10\%) [4].

Best Management Practice (BMP) in the context of LID practice is a way that is considered to be the most efficient in managing rainfall runoff with minimal impact. The implementation of the LID approach is done by selecting and making LID units according to local needs [8].

\section{Methodology}

The data used in this research is secondary data. Some of the data used in this research are rainfall at FTUI rain gage station, UI catchment area contour and UI catchment area properties. The properties of UI catchment area required are land use, soil layers, river flow, and groundwater level. Rainfall data in FTUI rain station is obtained and then calculated. Using the rainfall data of the area affecting the UI catchment area, the calculation of the design rainfall uses the distribution method of Gumbel and Log Pearson III. To determine the distribution method to be used, the distribution fit test is done using Chi-Square and Smirnov-Kolmogorov method. 
In this study, ArcGIS software is used to identify $\mathrm{CN}$ values for UI catchment area. $\mathrm{CN}$ values are obtained based on the extent of existing land use. The usage of ArcGIS software will be widely available for each land use in UI catchment area. In the Arc-GIS software, there is a feature of Best Management Practices (BMP) Siting Tools created to assist in the selection of suitable locations for different types of LID concepts. The parameters used in BST for physical criteria for placement of BMPs are drainage/slope, hydrological soil group, groundwater table depth, road border, river border/channel, and the border of the building.

\section{Results and discussion}

\subsection{Properties of Universitas Indonesia catchment area}

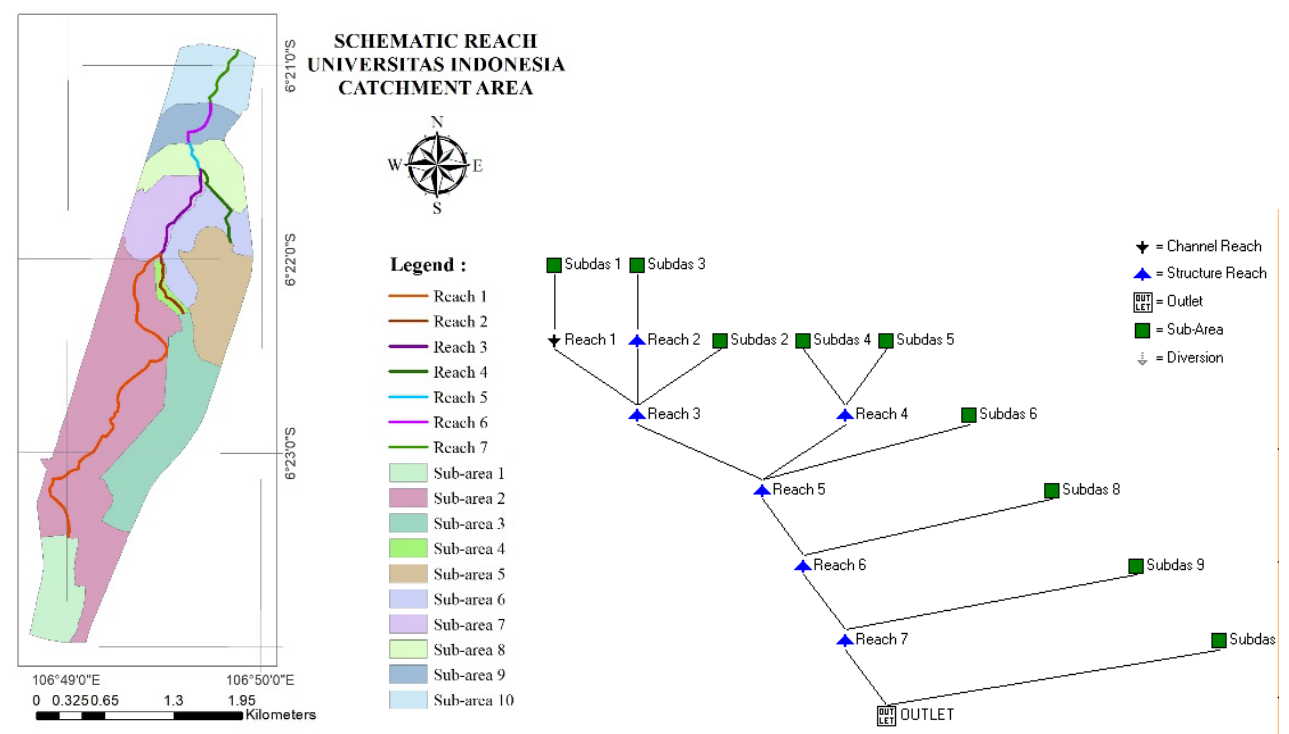

Fig. 1. Subarea and schematic reach Universitas Indonesia catchment area.

Universitas Indonesia catchment area is located on the border between West Java Province and DKI Jakarta Province. Universitas Indonesia catchment area is located in the administrative area of Beji Subdistrict and Pancoran Mas Subdistrict, Depok City. Area of Universitas Indonesia catchment area is approximately $579.16 \mathrm{Ha}$. The southern boundary of the Universitas Indonesia catchment area is the residential area of Kemiri Muka Subdistrict, and at the nothern boundary is the dormitory. Regency of Kukusan in the west is bordered by Bogor-Jakarta railway.

Using ArcGIS software, subdividing details of each sub-area in the UI catchment area in Table 1 are obtained.

The upstream of Universitas Indonesia catchment area comes from Situ Rawa Besar located in Kemiri Muka Subdistrict, and its downstream is in the outlet of pond Salam UI. Viewed from the channel flow in Universitas Indonesia catchment area, 7 reaches are connecting each sub-catchment with reach properties in Table 2, $\mathrm{t}$ is assumed that there is no change in cross-sectional shape in one reach.

It can be seen that 5 of the 7 reach is in the form of structure, it is because the lake is in catchment area university Indonesia in the form of overflow. 
Table 1. Area of each sub-catchments in UI Campus Depok catchment area.

\begin{tabular}{|c|c|c|c|}
\hline No. & Name & Area (ha) & Information \\
\hline 1. & Subdas 1 & 37.49 & Rawa Besar Pond \\
\hline 2. & Subdas 2 & 214.01 & Kemiri Muka Residence \\
\hline 3. & Subdas 3 & 80.31 & Kemiri Muka Residence \\
\hline 4. & Subdas 4 & 6.54 & Agathis Pond \\
\hline 5. & Subdas 5 & 58.82 & Kenanga Pond \\
\hline 6. & Subdas 6 & 38.19 & Faculty of Social Science and Cultural Science \\
\hline 7. & Subdas 7 & 38.08 & Mahoni Pond \\
\hline 8. & Subdas 8 & 36.58 & Puspa Pond \\
\hline 9. & Subdas 9 & 26.44 & Ulin Pond \\
\hline 10. & Subdas 10 & 42.70 & 579.16 \\
\hline \multicolumn{2}{|c|}{ Total area (Ha) } & &
\end{tabular}

Table 2. Properties Reach of Universitas Indonesia catchment area.

\begin{tabular}{|c|c|c|c|}
\hline Reach & Reach length (m) & Manning & Type \\
\hline Reach 1 & $3,781.07$ & 0.012 & Channel \\
\hline Reach 2 & 651.38 & 0.03 & Structure \\
\hline Reach 3 & 990.44 & 0.012 & Structure \\
\hline Reach 4 & 785.92 & 0.012 & Channel \\
\hline Reach 5 & 274.60 & 0.03 & Structure \\
\hline Reach 6 & 525.34 & 0.03 & Structure \\
\hline Reach 7 & 610.62 & 0.03 & Structure \\
\hline
\end{tabular}

\subsection{Hydrological analysis}

In this study, the rainfall data used is the maximum annual rainfall data in Faculty Engineering Universitas Indonesia (FTUI) rain gage station (Table 3). Because this calculation will continue to identify the LID infrastructure, where the LID concept is only suitable for rain in the low to moderate spectrum, so the return period to be used is $2,5,10$, and 25 years. The distribution in this research is the distribution of Gumbel and Log Pearson Type III. In determining the distribution of rain to be used for subsequent calculations, a distribution alignment test is performed. In this study, the alignment test carried out is a test of Chi-Square and Smirnov-Kolmogorov Test.

Based on the results of alignment test distribution of rain used is the distribution of Log Pearson Type III. With a large rain plan used is shown in Table 4. 
Table 3. Rainfall data in FTUI rain gage station.

\begin{tabular}{|c|c|c|}
\hline \multicolumn{3}{|c|}{ FTUI Rain gage } \\
\hline No. & Year & Rainfall (mm) \\
\hline 1 & 2003 & 102 \\
\hline 2 & 2004 & 118 \\
\hline 3 & 2005 & 107 \\
\hline 4 & 2006 & 93.5 \\
\hline 5 & 2007 & 160.2 \\
\hline 6 & 2008 & 156 \\
\hline 7 & 2009 & 137 \\
\hline 8 & 2010 & 109 \\
\hline 9 & 2011 & 121 \\
\hline 10 & 2012 & 94.2 \\
\hline 11 & 2013 & 101.7 \\
\hline 12 & 2014 & 151.5 \\
\hline 13 & 2015 & 97.2 \\
\hline 14 & 2016 & 142.8 \\
\hline 15 & 2017 & 108 \\
\hline & & \\
\hline
\end{tabular}

Table 4. Design rainfall of Universitas Indonesia catchment area.

\begin{tabular}{|c|c|}
\hline Return period & Design rainfall (mm) \\
\hline 2 & 109.90 \\
\hline 5 & 130.01 \\
\hline 10 & 143.17 \\
\hline 25 & 159.69 \\
\hline
\end{tabular}

\subsection{Hydrological analysis}

For Universitas Indonesia catchment area land use obtained from maps of Satellite Image 2015 that have been harmonized with the conditions in the field, acquired land use Fig. 2. With land use for existing conditions, flood hydrographs are found for the 2, 5, 10 and 25 annual repeat periods as in Fig. 3. There are two flood peaks due to the distribution of rain that used to experience two times in a day that is at the 5th hour and 16th hour. Based on the obtained hydrograph results, the maximum discharge peak with 2, 5, 10 and 25 annual repeat periods of $10.77,15.70,19.48$, and $24.33 \mathrm{cms}$. Also, from the hydrograph that has 
been formed, then the volume of runoff for each period can be calculated from the area of each hydrograph.

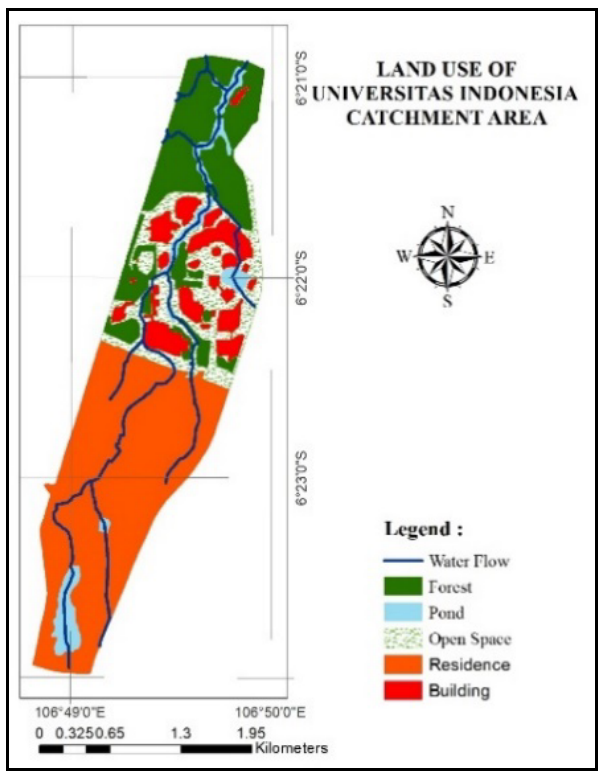

Fig. 2. Land use of Universitas Indonesia catchment area.

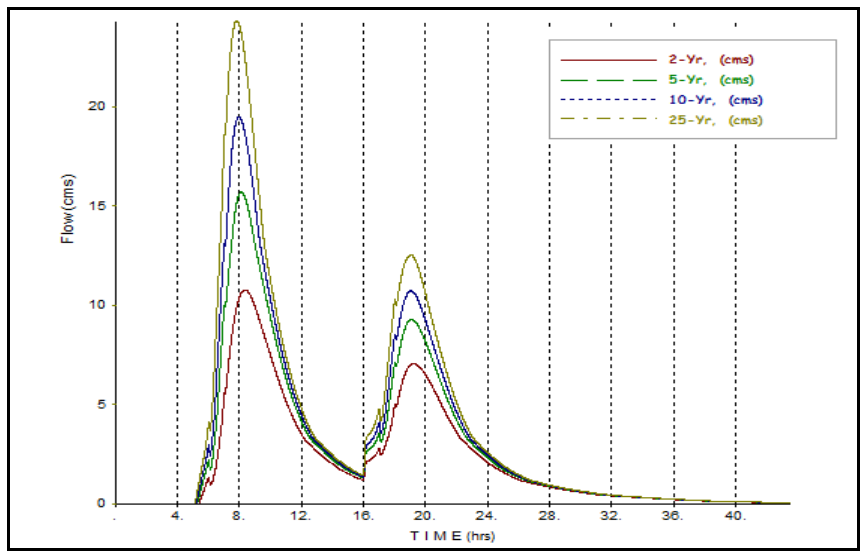

Fig. 3. Design flood hydrograph.

\subsection{Simulation result BMP siting tools in Universitas Indonesia catchment area}

In this study, various land-use simulations were carried out (Fig. 4). Research begins by using land use for the existing condition, followed by various kinds of LID technology based on running BMP Siting Tools. Technology that can be implemented according to the results of running BMP Siting Tool is bioretention, grassed swales, infiltration basin, infiltration trench, vegetated filter strip, porous pavement, rain barrel, nonsurface, and sand filter surface. Also, BMP Siting Tools also provides another proposal in the form of a combination of two or more BMP technologies. From the proposed laying of LID-BMPs technology will get the change in the value of the curve number based on each proposal. 

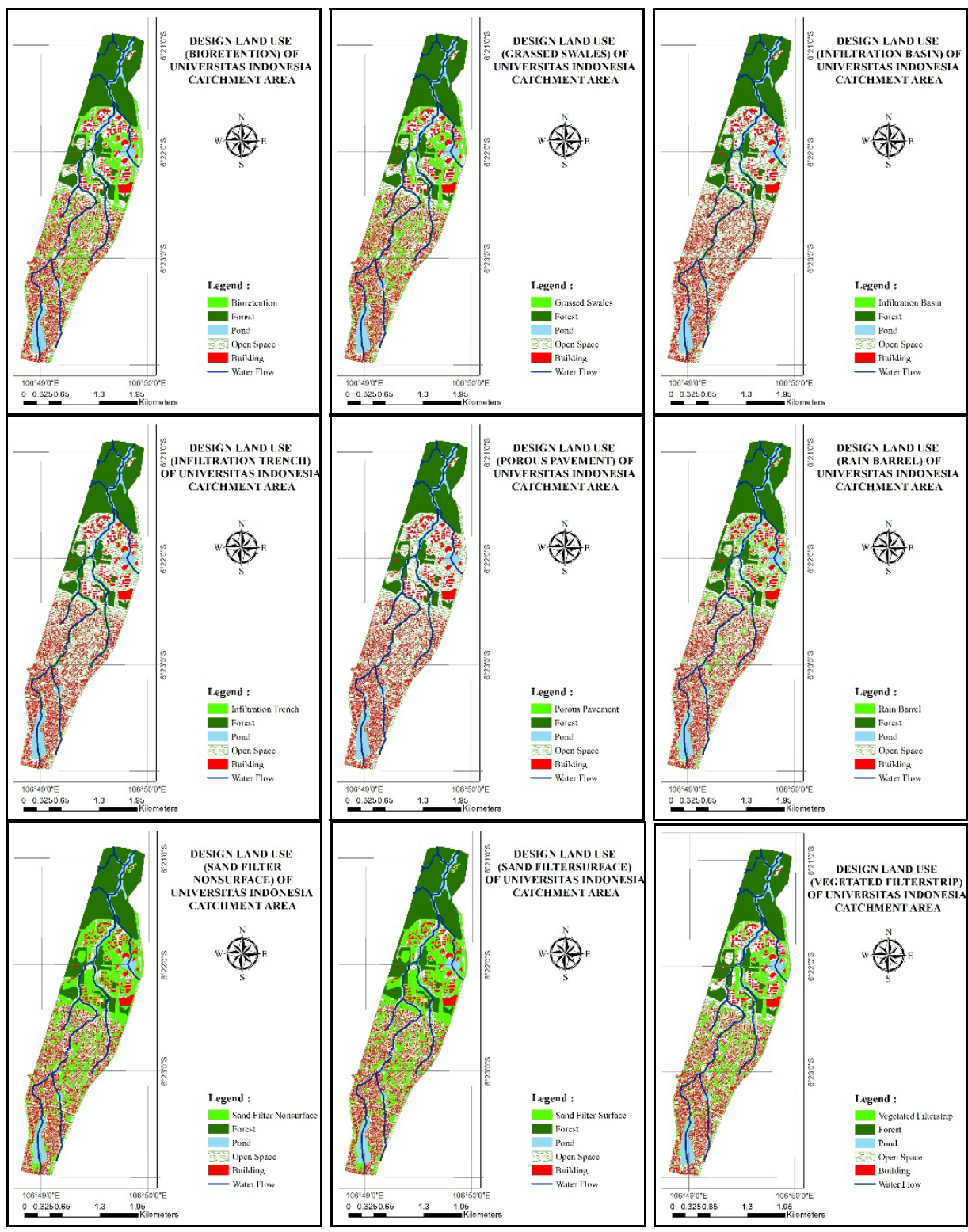

Fig. 4. Design land use of Universitas Indonesia catchment area.
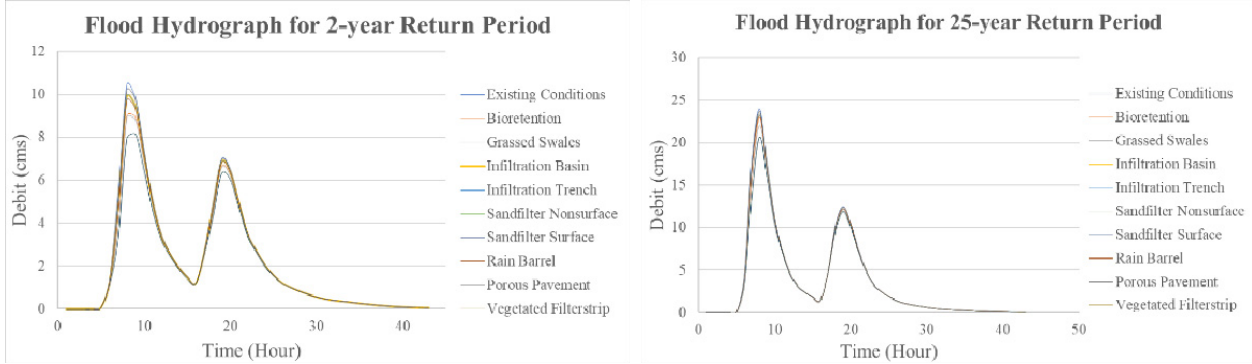

Fig. 5. Flood hydrograph for 2-year and 25-year return period. 
Due to land use change, peak flow for 2-year and 25-year return period rainfall in the outlet section decreased. For comparison of hydrograph peak decreases from the $2^{\text {nd }}$ and $25^{\text {th }}$ anniversary periods of each LID infrastructure type can be seen in Fig. 5. From the results of Win-TR 55, it can be calculated the volume of runoff for the existing condition and simulation application of LID-BMPs technology and the effectiveness of each technology LID-BMPs in DTA Campus UI Depok as in Table 5.

Table 5. Effectivity calculation of each LID-BMP technologies.

\begin{tabular}{|c|c|c|c|c|c|c|c|c|c|}
\hline \multirow{3}{*}{ No } & \multirow{3}{*}{$\begin{array}{l}\text { LID-BMP } \\
\text { Technologies }\end{array}$} & \multicolumn{8}{|c|}{ Return Period } \\
\hline & & \multicolumn{2}{|c|}{2 Year } & \multicolumn{2}{|c|}{5 Year } & \multicolumn{2}{|c|}{10 Year } & \multicolumn{2}{|c|}{25 Year } \\
\hline & & $\begin{array}{c}\text { Peak } \\
\text { flow } \\
\text { (cms) }\end{array}$ & $\begin{array}{c}\text { Effect } \\
\text {-ivity } \\
(\%)\end{array}$ & $\begin{array}{c}\text { Peak } \\
\text { flow } \\
\text { (cms) }\end{array}$ & $\begin{array}{c}\text { Effecti- } \\
\text { vity } \\
(\%)\end{array}$ & $\begin{array}{l}\text { Peak } \\
\text { flow } \\
\text { (cms) }\end{array}$ & $\begin{array}{c}\text { Effect } \\
\text {-ivity } \\
\text { (\%) }\end{array}$ & $\begin{array}{l}\text { Peak } \\
\text { flow } \\
\text { (cms) }\end{array}$ & $\begin{array}{c}\text { Effect } \\
\text {-ivity } \\
\text { (\%) }\end{array}$ \\
\hline 1 & $\begin{array}{l}\text { Existing } \\
\text { condition }\end{array}$ & 11.93 & - & 17.54 & - & 21.57 & - & 26.71 & \\
\hline 2 & Bioretention & 10.55 & 11.57 & 15.56 & 11.29 & 19.45 & 9.83 & 24.45 & 8.46 \\
\hline 3 & $\begin{array}{l}\text { Grassed } \\
\text { swales }\end{array}$ & 10.54 & 11.65 & 15.55 & 11.35 & 19.44 & 9.87 & 24.44 & 8.50 \\
\hline 4 & $\begin{array}{l}\text { Infiltration } \\
\text { basin }\end{array}$ & 11.34 & 4.95 & 16.7 & 4.79 & 20.67 & 4.17 & 25.75 & 3.59 \\
\hline 5 & $\begin{array}{l}\text { Infiltration } \\
\text { trench }\end{array}$ & 11.34 & 4.95 & 16.7 & 4.79 & 20.67 & 4.17 & 25.75 & 3.59 \\
\hline 6 & $\begin{array}{c}\text { Sandfilter } \\
\text { nonsurface }\end{array}$ & 8.56 & 28.25 & 12.61 & 28.11 & 16.06 & 25.54 & 20.69 & 22.54 \\
\hline 7 & $\begin{array}{l}\text { Sandfilter } \\
\text { surface }\end{array}$ & 8.56 & 28.25 & 12.61 & 28.11 & 16.06 & 25.54 & 20.69 & 22.54 \\
\hline 8 & Rain barrel & 11.2 & 6.12 & 16.49 & 5.99 & 20.45 & 5.19 & 25.52 & 4.46 \\
\hline 9 & $\begin{array}{l}\text { Vegetated } \\
\text { filterstrip }\end{array}$ & 10.39 & 12.91 & 15.31 & 12.71 & 19.19 & 11.03 & 24.17 & 9.51 \\
\hline 10 & $\begin{array}{c}\text { Porous } \\
\text { pavement }\end{array}$ & 11.7 & 1.93 & 17.22 & 1.82 & 21.23 & 1.58 & 26.34 & 1.39 \\
\hline
\end{tabular}

From the table, it appears that the greatest effectiveness for lowering the runoff volume is in the rain with a 2-year return period. According to Stephens et al. [4], LID is only suitable for managing rainfall on the low to moderate spectrum. The greater the repeated period, then the effectiveness of these technologies to reduce the volume of flow will be smaller, and then the largest flood peak decrease by using sand filter non-surface or sand filter surface infrastructure.

\section{Conclusions}

Based on the results of research and discussion that has been presented, it can be concluded as follows. Technology that can be implemented according to the result of running BMP 
Siting Tool is bioretention, grassed swales, infiltration basin, infiltration trench, vegetated filter strip, porous pavement, rain barrel, non-surface sand filter, and sand filter surface. By applying said infrastructures, the reduction of peak flow on various rain spectrums vary from $3-30 \%$. The effectiveness of flood peak discharge can be obtained by using sand filter non-surface or sand filter surface infrastructure. With the addition of LID concept buildings, the largest peak flow decline occurred in the $2 n$-year design rainfall because LID is the concept to manage rain in the light to the moderate spectrum. LID concept is very suitable to be applied to urban areas that have limited open land by utilizing the land around as much as possible so that rainwater in the low spectrum can be restrained above the surface of the soil that then seeps into the soil.

This research is supported by research funds made available through the Research Fund of PITTA (Publikasi Terindeks Internasional Untuk Tugas Akhir Mahasiswa UI) of Universitas Indonesia, 2018 (Contract number: 2422/UN2.R3.1/HKP.05.00/2018)

\section{References}

1. Y. Sudaryoko, Pedoman penanggulangan banjir (Departemen Pekerjaan Umum, Jakarta, 1987)

2. A.G. Cudworth, Jr. Flood hydrology manual. A water resources technical publication (US Department of the Interior, Denver, 1989)

3. US Enviromental Protection Agency. Benefits of low impact development (USEPA, Washington, DC, 2012)

4. K.A. Stephens, P. Graham, D. Reid, Stromwater planning: A guidebook for British Columbia (BC Ministry of Environment, 2002)

5. Berlin Senate for Urban Development Communications, Rainwater management concept: greening buildings, cooling buildings (Ministerial Building Affairs, Berlin, 2010)

6. S. Darsono, Berkala Ilmiah Teknik Keairan 13, 4 (2007)

7. L. Coffman, Low-impact development design strategies, an integrated design approach (Department of Environmental Resources, Maryland, 1999)

8. Selvakumar, S. Muthukrishnan, B. Madge, R. Field, A. Tafuri. The use of best management practices (BMPs) in urban watersheds (DEStech Pub. Pennsylvania, 2004) 